\title{
Protein deficiency in spaced-fed rats
}

\author{
By S. R. PADWALDESAI, V. NINJOOR, T. V. RAMAKRISHNAN, \\ P. L. SAWANT, U. S. KUMTA AND A. SREENIVASAN \\ Biochemistry $\Xi^{\circ}$ Food Technology Division, Bhabha Atomic Research Centre, \\ Trombay, Bombay 74, India
}

(Received I8 November 1968-Accepted 14 April 1969)

\begin{abstract}
1. Adult rats were trained to consume the entire day's ration in $2 \mathrm{~h}$. They showed marked difference in food intake when a diet lacking in protein was given. Two broad stages were observed, the first phase did not show any drop in calorie intake whereas the second showed distinct severe calorie deficiency.

2. Definite changes were noted in the metabolic profiles of the protein-deficient group even though no evidence for a fall in calorie intake (stage $\mathrm{I}$ ) was provided by the measurements of body and organ weights, urinary end-products, liver constituents and liver enzymes.

3. The levels of urinary end-products and liver DNA and RNA decreased in the proteindeficient and pair-fed control groups compared with the control group.

4. The liver glycogen content remained unchanged in the protein-deficient groups whereas the lipid content and the ratio of vitamin $A$ alcohol to ester increased significantly.

5. The activity of xanthine oxidase in the liver was reduced by $75 \%$ in the pair-fed control group and by $95 \%$ in the protein-deficient group when compared with the control group. However, the activity of succinic dehydrogenase varied, depending on the unit of activity used to express it.
\end{abstract}

Manifestations of adverse effects of feeding protein-free and low-protein diets to experimental animals have been extensively reported (Platt, Heard \& Stewart, 1964). However, in such experiments, rats were fed protein-free diets ad lib. for periods varying from 3 to 84 days and, since dietary intake is severely depressed in ad lib. feeding, the results obtained reflect changes due to 'protein-calorie malnutrition' (Platt et al. 1964). It is difficult to dissociate the effects of a protein-free feeding regimen from those of calorie deficiency. A force-feeding technique has therefore been used to study the effects of diets devoid of protein or amino acids (Adamstone \& Spector, 1950; Samuels, Goldthorpe \& Dougherty, I95I; Van Pilsum, Speyer \& Samuels, I957; Spector \& Adamstone, I950; Sidransky \& Farber, 1958; Sidransky \& Rechcigl, 1962; Sekhara Varma \& Hanumantha Rao, 1966), in spite of the obvious limitations that it will not reveal the effect of a protein-free feeding regimen on food intake.

This communication reports the effects of protein deficiency in adult rats trained to eat the entire day's food in a short period (Sekhara Varma \& Hanumantha Rao, 1966; Kumta, Harper \& Elvehjem, 1958). The procedure permits study of metabolic adaptation and physiological alterations caused by protein-free diets with defined calorie intake. Body and organ weights, liver constituents, activities of liver xanthine oxidase and succinic dehydrogenase and urinary end-products have been measured. 


\section{EXPERIMENTAL}

\section{Diets}

Stock diets. The laboratory stock diet contained wheat, bengal gram, fish meal, yeast, and sesame oil containing shark-liver oil ( $3: 1)$, all mixed together in the ratio of $7: 2: 0 \cdot 5: 0 \cdot 4: 0 \cdot 1$ by weight.

Basal diet. The basal diet contained ( $\mathrm{g} / \mathrm{I} 00 \mathrm{~g}$ ) casein II, methionine $\mathrm{O} \cdot \mathrm{I}$, salt mixture (Kumta \& Harper, 1962) 5, sesame oil containing fat-soluble vitamins 5 , vitamin supplements (Kumta \& Harper, 1962) 0.25, and choline chloride 0.15. Maize starch as the carbohydrate source was added to make up to $100 \mathrm{~g}$. The method of preparation of the basal diet from these ingredients has been outlined by Kumta \& Harper (1962).

The compositions of the salt and vitamin mixtures were:

\begin{tabular}{lc}
\multicolumn{1}{c}{ Salts $(\mathrm{g} / \mathrm{I} 00 \mathrm{~g})$} \\
$\mathrm{CaCO}_{3}$ & 29.29 \\
$\mathrm{CaHPO}_{4} \cdot 2 \mathrm{H}_{2} \mathrm{O}$ & 0.43 \\
$\mathrm{KH}_{2} \mathrm{PO}_{4}$ & $34 \cdot 3 \mathrm{I}$ \\
$\mathrm{NaCl}$ & 25.06 \\
$\mathrm{MgSO}_{4} \cdot 7 \mathrm{H}_{2} \mathrm{O}$ & 9.98 \\
$\mathrm{Fe}\left(\mathrm{C}_{6} \mathrm{H}_{5} \mathrm{O}_{7}\right) \cdot 6 \mathrm{H}_{2} \mathrm{O}$ & 0.623 \\
$\mathrm{CuSO}_{4} \cdot 5 \mathrm{H}_{2} \mathrm{O}$ & 0.156 \\
$\mathrm{MnSO}_{4} \cdot \mathrm{H}_{2} \mathrm{O}$ & $0.12 \mathrm{I}$ \\
$\mathrm{ZnCl}$ & 0.02 \\
$\mathrm{KI}$ & 0.0005 \\
$\left(\mathrm{NH}_{4}\right)_{6} \mathrm{MO}_{7} \mathrm{O}_{24} \cdot 4 \mathrm{H}_{2} \mathrm{O}$ & 0.0025
\end{tabular}

\begin{tabular}{lc}
\multicolumn{1}{c}{ Vitamins (mg/loo g diet) } \\
Thiamine hydrochloride & 0.5 \\
Riboflavine & 0.5 \\
Nicotinic acid & 2.5 \\
Calcium pantothenate & 2.0 \\
Pyridoxine hydrochloride & 0.25 \\
Menaphthone & 0.05 \\
Biotin & 0.01 \\
Folic acid & 0.02 \\
Vitamin $\mathbf{B}_{\mathbf{1 2}}$ & 0.002 \\
Inositol & 10.0 \\
Ascorbic acid & 5.0
\end{tabular}

The fat-soluble vitamin mixture provided, per roo $\mathrm{g}$ diet, $10 \mathrm{mg} \alpha$-tocopherol, 400 i.u. vitamin A, and 200 i.u. vitamin D.

Protein-free diet. This was prepared from the basal diet by replacing casein and methionine with maize starch.

\section{Animals and their training}

Spaced-feeding procedure. About forty male rats of the Wistar strain, each weighing I00-I IO g were trained to consume the entire day's food in 2 h (Kumta et al. I958; Sekhara Varma \& Hanumantha Rao, I966). For this purpose, the laboratory stock diet was given for only $2 \mathrm{~h}$ each day during the Ist week, and was then replaced by the basal diet for the next 4-5 weeks. The training period resulted in an initial loss in weight due to low food intake but the rats gained weight after a week and increased their dietary intake. Further, to eliminate possible effects, if any, of initial growth depression, the rats were continued on training for a period of 40 days (Fig. I).

At the end of the training period, the rats which showed consistently uniform gain in weight $(216 \mathrm{~g})$ and consumed nearly the same amount of diet (II g/day) were selected. They were separated into three groups each consisting of five rats. Groups I and 2 were given, respectively, the protein-free diet and the basal diet. Since protein deficiency may cause a drop in food intake, a pair-fed control group was also included (group 3), which received the basal diet equal in amount to that consumed by group I.

Ad lib. feeding procedure. Male Wistar rats maintained on the stock colony diet, of average weight $216 \mathrm{~g}$, were selected to serve as pair-weight controls of the rats used in 
the spaced-feeding procedure. They were separated into two groups each consisting of five rats which were given the basal (group 4) and protein-free (group 5) diets. Since there was a severe drop in food intake of group 5, within 3 days, followed by daily spillage of diet, the experiment was discontinued after 6 days. Daily changes in body-weight and food intake were noted. Urine samples were collected every day and analysed for nitrogen (Umbreit, Burris \& Stauffer, I957), $\alpha$-amino nitrogen (Albanese \& Irby, I944), uric acid (Brown, I945), allantoin (Young \& Conway, 1942), and inorganic phosphorous (Fiske \& Subbarow, 1929). Faecal nitrogen was determined by the Kjeldahl method (Umbreit et al. I957). Rats were killed by decapitation; the liver, kidney and spleen were removed immediately and weighed. The chilled liver samples were used for the determination of nucleic acids (Schneider, 1946), glycogen (Montgomery, 1957), total lipids (Folch, Lees \& Stanley, 1957) and vitamin A alcohol and ester ('Thompson, Ganguly \& Kon, 1949).

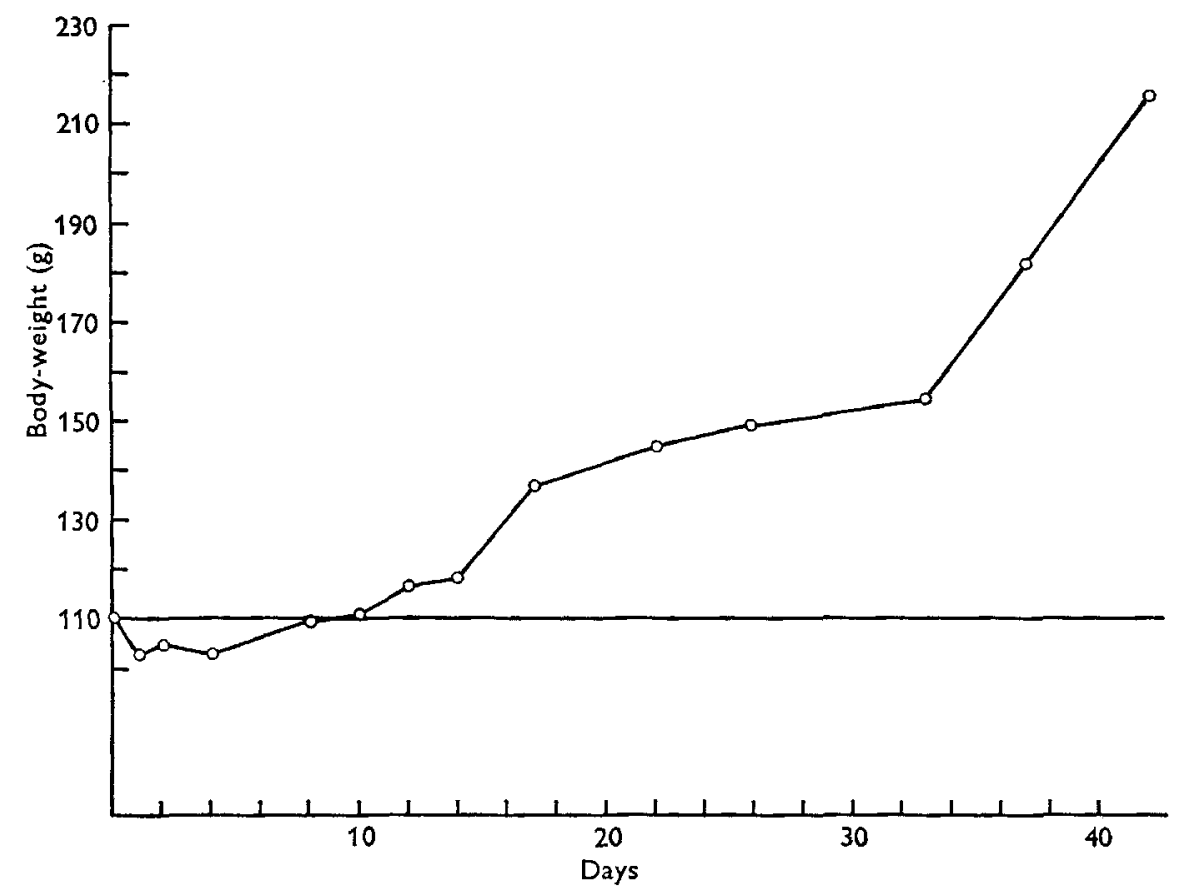

Fig. 1. Body-weights of rats during the training period.

The $10 \%$ homogenate of livers prepared in $0.25 \mathrm{M}$-sucrose containing $0.00 \mathrm{I} \mathrm{M-}$ EDTA was used for manometric measurement of xanthine oxidase (Dhungat \& Sreenivasan, 1954) and succinic dehydrogenase (Umbreit et al. 1957).

\section{RESULTS}

Diet consumption. Fig. 2 shows the influence of feeding procedures on the food intake of rats given a protein-deficient diet. In the rats fed $a d$ lib., the calorie deficiency occurred immediately after ingestion of the protein-deficient diet, which was followed 
by severe symptoms of protein deficiency. Subsequently, owing to spilling of diets by the rats on the protein-deficient diet, food consumption could not be accurately measured.

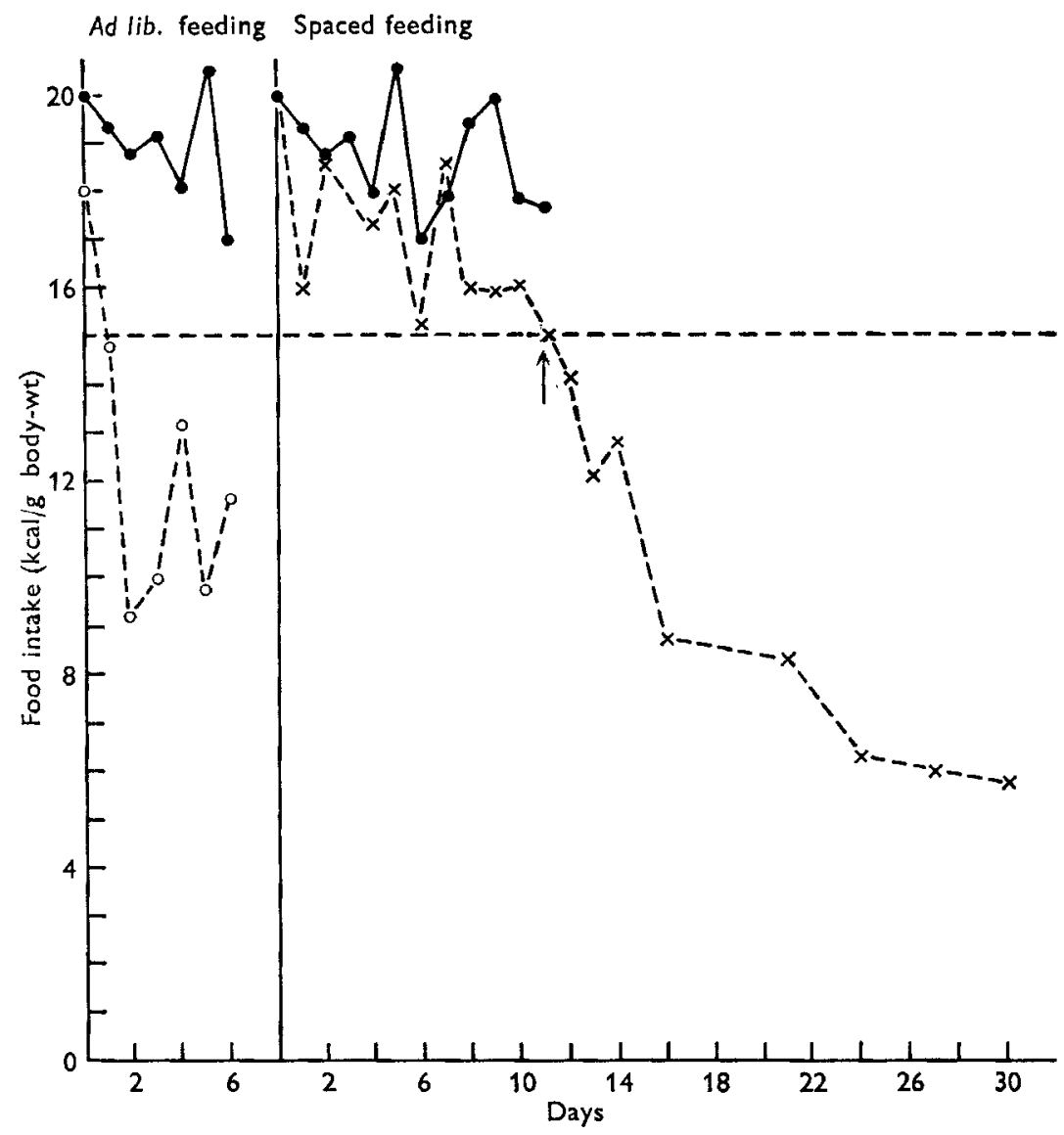

Fig. 2. Food consumption of spaced-fed rats and of rats fed ad lib. - - control group for both the feeding procedures; $x---x$, spaced-fed on a protein-free diet; $O--0$, fed ad lib. on a protein-free diet. The arrow indicates the duration of the first stage of calorie deficiency in the spaced-fed animals when given the protein-free diet.

In contrast, the spaced-fed rats could continue to consume IO-II g/day of the protein-deficient diet for which this group was trained, up to I I days. Subsequently, this group also showed a severe drop in food consumption as observed with the animals fed $a d$ lib. In the rats given the basal diet the pattern of food intake was the same irrespective of the feeding procedure.

Body and organ weights. The effect of the two feeding procedures on body-weight is illustrated in Fig. 3. Control rats fed on the basal diet either ad lib. or by the spacedfeeding technique showed similar gains in weight. No change in weight was observed with the pair-fed controls. Loss in body-weight of about $30 \mathrm{~g}$ occurred in 5 days with the protein-deficient group fed $a d$ lib. as compared with I I days for the spaced-fed animals on the protein-free diet, showing the effect of the two feeding procedures on 
rate of loss of body-weight. Table I gives values for the weights of organs from rats given the control and protein-free diets $a d$ lib. or by the spaced-feeding technique. There was a marked decrease in the weights of livers, kidneys and spleens of the rats maintained on the protein-free diet.

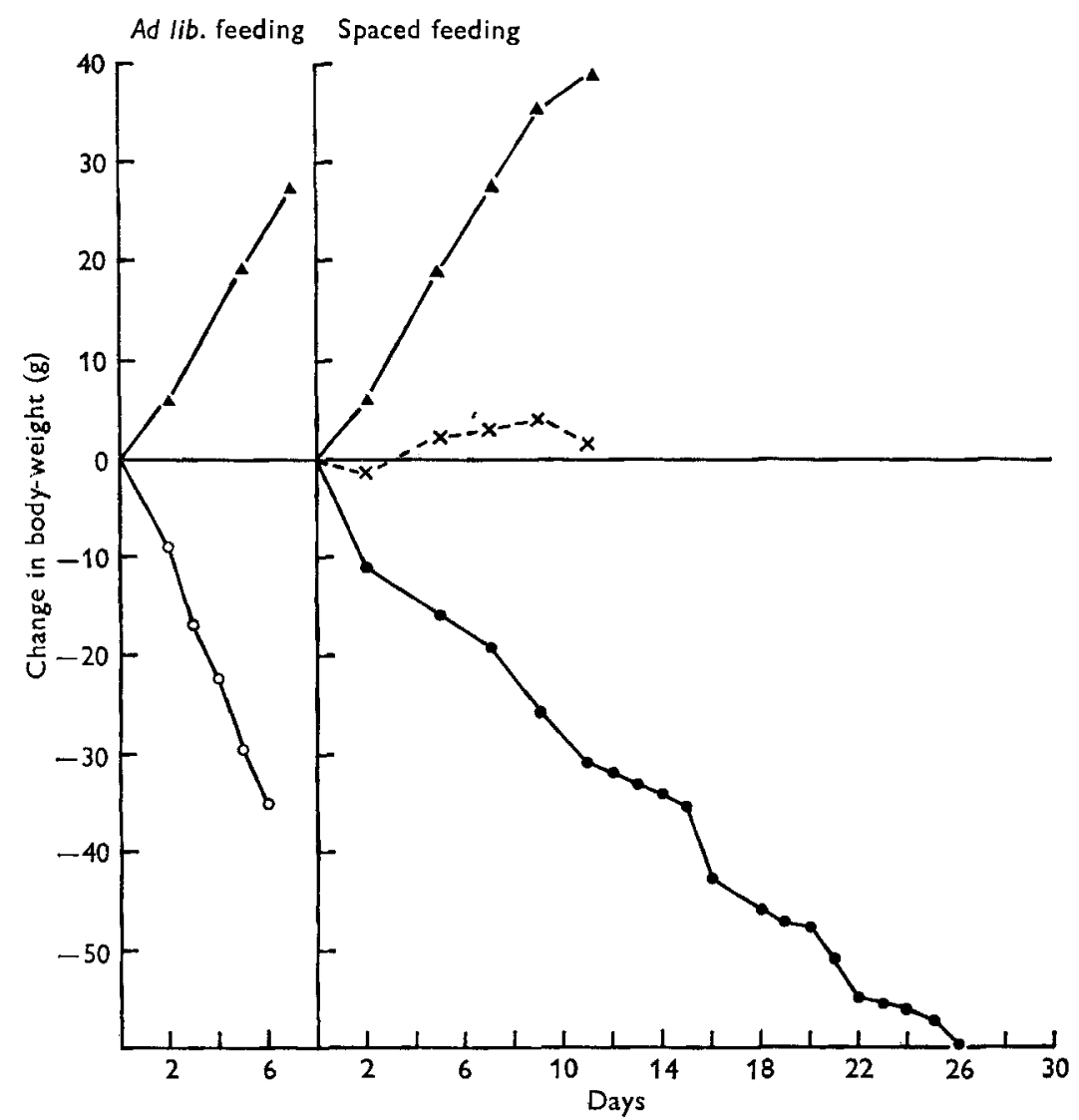

Fig. 3. Body-weights of spaced-fed rats and of rats fed ad lib. $\mathbf{\Delta - \Delta}$, control group for both the feeding procedures; $\mathrm{O}-\mathrm{O}$, fed $a d \mathrm{lib}$. on a protein-free diet; $\times-{ }_{-} \times$, spaced-fed basal diet as pair-fed controls; -1 , spaced-fed on a protein-free diet.

Table I. Organ weights of groups of five rats, killed after I I days of spaced-feeding or after 6 days of feeding ad lib.

\section{Group}

I (spaced-fed, protein-free diet)

2 (spaced-fed, basal diet)

4 (fed ad lib., basal diet)

5 (fed ad lib., protein-free diet)

$$
\begin{aligned}
& \text { Liver (g) } \\
& 5 \cdot 8 \pm 0.60 \\
& 7 \cdot 3 \pm 0.95 \\
& 5 \cdot 3 \pm 0.35
\end{aligned}
$$

$$
\begin{gathered}
\text { Spleen (mg) } \\
298 \pm 31 \\
482 \pm 35 \\
310 \pm 30
\end{gathered}
$$

Nitrogen balance and urinary products. Table 2 summarizes the results of analyses of pooled urine samples from spaced-fed rats collected during days I-3 and 9-I I. Beyond II days, urine samples were not analysed, since severe calorie deficiency developed in the protein-deficient group thereafter. While the diet supplied to groups 2 
and 3 contained I $\%$ casein, group I was fed on a diet devoid of protein. This resulted in severe negative nitrogen balance on the Ist day after the basal diet was changed to the protein-deficient diet.

\section{Table 2. Urinary end-products* of spaced-fed rats}

(Mean values with their standard errors for groups of five rats)

\begin{tabular}{|c|c|c|c|c|c|c|}
\hline Group & Days & Nitrogen & $\begin{array}{r}\alpha \text {-Amino } \\
\text { nitrogen }\end{array}$ & Uric acid & Allantoin & $\begin{array}{l}\text { Inorganic } \\
\text { phosphate }\end{array}$ \\
\hline $\begin{array}{l}\text { I (spaced-fed, } \\
\text { protein- } \\
\text { free diet }\end{array}$ & $\begin{array}{l}I-3 \\
9-I I\end{array}$ & $\begin{array}{c}137 \cdot 7 \pm 12 \cdot 10 \\
70 \cdot 7 \pm 3 \cdot 75\end{array}$ & $\begin{array}{l}6.6 \pm 0.27 \\
2.9 \pm 0.31\end{array}$ & $\begin{array}{l}4.22 \pm 0.43 \\
1 \cdot 71 \pm 0.32\end{array}$ & $\begin{array}{l}40 \cdot 6 \pm 2 \cdot 38 \\
20 \cdot 8 \pm I \cdot 6 I\end{array}$ & $\begin{array}{c}108 \cdot 4 \pm 12 \cdot 3 \\
6 I \cdot 8 \pm 7 \cdot 8\end{array}$ \\
\hline 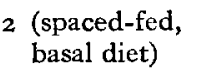 & $\begin{array}{l}I-3 \\
9-I I\end{array}$ & $\begin{array}{l}185.9 \pm \text { I1.5 } \\
172 \cdot 0 \pm 3.85\end{array}$ & $\begin{array}{l}8 \cdot 2 \pm I \cdot I \\
6 \cdot 9 \pm 0.87\end{array}$ & $\begin{array}{l}5.36 \pm 0.12 \\
5.61 \pm 0.31\end{array}$ & $\begin{array}{l}5 I \cdot 74 \pm 3 \cdot 14 \\
46 \cdot 27 \pm 0 \cdot 31\end{array}$ & $\begin{array}{l}259^{\circ} 6 \pm 13^{\circ} \\
265^{\circ} 0 \pm 5^{\cdot I}\end{array}$ \\
\hline $\begin{array}{l}3 \text { (spaced-fed, } \\
\text { basal diet, as } \\
\text { pair-fed contr }\end{array}$ & $\begin{array}{l}I-3 \\
9^{-I I} \\
\text { col) }\end{array}$ & $\begin{array}{l}151 \cdot 5 \pm 7 \cdot 5 \\
122 \cdot 9 \pm 8 \cdot 95\end{array}$ & $\begin{array}{l}6.7 \pm 0.41 \\
3.1 \pm 0.19\end{array}$ & $\begin{array}{l}4.05 \pm 0.29 \\
4.13 \pm 0.51\end{array}$ & $\begin{array}{l}47 \cdot 1 \pm 1 \cdot 3 \\
20 \cdot 3 \pm 0 \cdot 63\end{array}$ & $\begin{array}{l}163.9 \pm 9 \cdot 8 \\
\text { I } 60.8 \pm \text { I I.3 }\end{array}$ \\
\hline
\end{tabular}

* Nitrogen, $\alpha$-amino nitrogen, uric acid and allantoin levels are expressed as $\mathrm{mg} / 24 \mathrm{~h}$ urine; inotganic phosphate level is expressed as $n$-moles $/ 24 \mathrm{~h}$ urine.

Table 3. Liver xanthine oxidase and succinic dehydrogenase activities in groups of five rats, killed after II days of spaced-feeding

(Mean values with their standard errors)

\begin{tabular}{|c|c|c|c|c|c|c|}
\hline \multirow[b]{2}{*}{ Group } & \multicolumn{3}{|c|}{ Xanthine oxidase* } & \multicolumn{3}{|c|}{ Succinic dehydrogenase* } \\
\hline & $\begin{array}{l}\text { Units/ } \\
\text { g liver }\end{array}$ & $\begin{array}{l}\text { Units/ } \\
\text { mg N }\end{array}$ & $\begin{array}{l}\text { Units/ } \\
\text { liver }\end{array}$ & $\begin{array}{l}\text { Units/ } \\
\text { g liver }\end{array}$ & $\begin{array}{l}\text { Units/ } \\
\text { mg N }\end{array}$ & $\begin{array}{l}\text { Units/ } \\
\text { liver }\end{array}$ \\
\hline $\begin{array}{l}\text { I (spaced-fed, protein-free } \\
\text { diet) }\end{array}$ & $5 \cdot 0 \pm 0.14$ & $0.04 \pm 0.001$ & $27 \pm 3$ & $172 \pm 8$ & $1 \cdot 5 \pm 0.035$ & $979 \pm 30$ \\
\hline $\begin{array}{l}2 \text { (spaced-fed, basal diet) } \\
3 \text { (spaced-fed, basal diet, as } \\
\text { pair-fed control) }\end{array}$ & $\begin{array}{l}40 \cdot 7 \pm 1 \cdot 39 \\
21 \cdot 0 \pm 0 \cdot 09\end{array}$ & $\begin{array}{l}0.23 \pm 0.03 \\
0.10 \pm 0.004\end{array}$ & $\begin{array}{l}497 \pm 14 \\
121 \pm 11\end{array}$ & $\begin{array}{l}180 \pm 9 \\
170 \pm 13\end{array}$ & $\begin{array}{l}1.0 \pm 0.02 \\
0.9 \pm 0.04\end{array}$ & $\begin{array}{r}1314 \pm 33 \\
983 \pm 21\end{array}$ \\
\hline
\end{tabular}

Even though groups 2 and 3 were both given the basal diet, they showed a difference in the pattern of excretion of urinary products. The decrease in the amounts of urinary products excreted by group 3 can be attributed to lower protein intake as compared with that of group 2. This difference increased further in group I, the reduction in the urinary excretion of nitrogen and of inorganic phosphate being 10 and $40 \%$ during days $\mathrm{I}-3$ and 40 and $60 \%$ during days $9-\mathrm{I}$ I respectively, when compared with that of group 3. The decreases in the amounts of other excretory products were observed during 9-I I days, when the excretion of $\alpha$-amino nitrogen and uric acid levels decreased by 15 and $58 \%$ respectively. The amount of allantoin excreted was not affected by protein deficiency.

Liver enzymes. The xanthine oxidase and succinic dehydrogenase activities of rat liver from spaced-fed rats are given in Table 3 . The xanthine oxidase activity was reduced by $75 \%$ in the pair-fed group, and by about $95 \%$ in the protein-deficient group when compared with the controls. The succinic dehydrogenase activity was reduced by $25 \%$ in the protein-deficient and pair-fed groups when expressed on the 
basis of total liver weight. However, this activity remained constant when expressed per $g$ liver, but increased by $50 \%$ when expressed per mg nitrogen in the proteindeficient group compared with the other two groups.

\section{Table. 4 Liver constituents of rats killed after I I days of spaced-feeding}

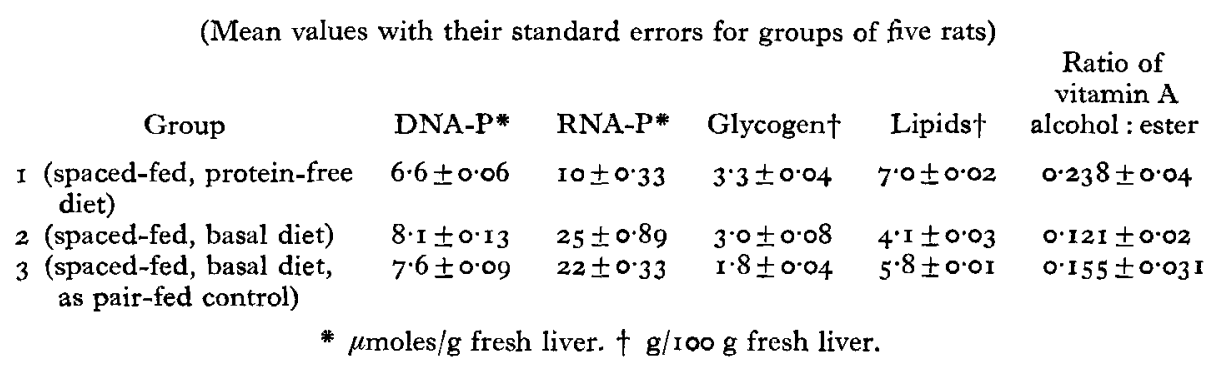

Liver constituents. Table 4 gives the value for liver constituents of the three groups of spaced-fed animals. Since the liver weights and liver nitrogen content of group I were found to be reduced, the values for liver constituents in Table 4 have been expressed per $\mathrm{g}$ liver.

It is interesting to note that in the livers of rats in group $\mathrm{I}$, given the proteindeficient diet, DNA and RNA were markedly reduced, but there was an accumulation of glycogen and lipids as compared with rats given the diet containing protein (groups 2 and 3 ). The increased accumulation of lipids due to protein deficiency would be also reflected in vitamin $A$ levels. In groups 2 and 3 , the contents of vitamin $A$ ester and alcohol were constant, but in the protein-deficient group vitamin A alcohol increased gradually with a concomittant fall in vitamin A ester. The ratio of vitamin $A$ alcohol to ester in the livers of this group after I I days was almost twice that found in group 2.

\section{DISCUSSION}

It is now understood that there is a relationship between a protein-free diet and the factors influencing dietary intake (Mayer, I955; Brobeck, I955, Lepkovsky, I953). The feeding procedure is known to influence the characteristics of protein deficiency. Thus, with ad lib. feeding, severe depression in food intake is considered as a manifestation of protein deficiency similar to marasmus (Platt et al. 1964). The forcedfeeding technique has been used to produce a kwashiorkor-type of symptom in experimental animals (Adamstone \& Spector, 1950; Samuels et al. 1951; Van Pilsum et al. 1957; Spector \& Adamstone, I950; Sidransky \& Farber, 1958; Sidransky \& Rechcigl, I962). When adult rats are spaced-fed depression in food intake occurs in two stages. The first stage, which follows a single feeding on a protein-deficient diet for $2 \mathrm{~h}$ and continues for about I I days, is characterized by a small but consistent drop in food intake (Fig. 2). In the second stage the depression in food intake is severe. These two stages cannot be dissociated in animals fed $a d l i b$. or by the forced-feeding procedure.

In animals fed ad lib. the effects of protein deprivation on nitrogen balance (Srikantia, Venkatachalam, Reddy \& Gopalan, 1964; Srikantia, I963; Adamstone \& Spector, 
1950), enzyme activities (Wainio, Eichel, Eichel, Person, Estes \& Allison, 1953; Rosen, Roberts \& Nichol, 1959; Prigmore, Bothwell \& Williams, 1955), and liver consitituents such as DNA (Thomson, Heagy, Hutchison \& Davidson, r953; Ely \& Ross, I95I; Williams, 1961 $a$ ), glycogen (Kosterlitz, 1947), lipids (Kosterlitz, 1947) and increase in the ratio of vitamin A alcohol to ester (Adhikari, Vakil \& Sreenivasan, 1968) are associated with the imposition of severe calorie deficiency. However, our present studies showed the occurrence of such changes during the early stage of calorie deficiency. Thus, levels of urinary nitrogen, inorganic phophorus and uric acid can be influenced by the combined effects of mild calorie deficiency and protein deficiency, whereas amino nitrogen and allantoin levels are affected similarly by either of these conditions. It is also interesting to note the presence of some xanthine oxidase activity even after I I days on the protein-free diet, and the partial effect of calorie deficiency in lowering the activity of this enzyme. This is in contrast with the complete disappearance of liver xanthine oxidase activity within 5 days (Muramatsu \& Ashida, 1962; Kazantseva \& Kaplanskii, 1956; Kshirsagar \& Patwardhan, 1958) when rats were fed ad lib. on a protein-free diet. Succinic dehydrogenase activity varied when expressed on different unit bases. This has also been reported by Williams ( $196 \mathrm{I} b$ ) when rats were fed $a d l i b$. on a proteinfree diet.

The reported alterations in the characteristics of subcellular components in protein deficiency are also influenced by high calorie deficiency (Williams, 196r $a, b$; Waterlow, I959; Narasinga Rao \& Radhakrishnan, 1966). It has not yet been ascertained whether similar changes occur in subcellular organelles during the first stage of protein deficiency in trained rats. Structural freedom for lysosomal enzymes under these conditions has been reported elsewhere.

The studies reported here show the division of manifestations of protein deficiency into two parts due to mild and severe calorie deficiencies associated with a proteinfree diet. Detailed studies on the metabolic adaptation regulating the first stage of deficiency in trained rats would be useful in elucidating the complex biochemical lesions of protein deficiency.

\section{REFEREN CES}

Adamstone, F. B. \& Spector, H. (r95o). Archs Path. 49, I73.

Adhikari, H. R., Vakil, U. K. \& Sreenivasan, A. (I968). Indian $\mathcal{F}$. Biochem. 5, I32.

Albanese, A. A. \& Irby, V. (1944). F. biol. Chem. 153, 583 .

Brown, H. (1945). F. biol. Chem. 158, 601.

Brobeck, J. R. (1955). Ann. N.Y. Acad. Sci. 64, 44.

Campbell, R. M. \& Kosterlitz, H. W. (1952), Science, N. Y. I15, 84.

Dhungat, S. B. \& Sreenivasan, A. (I954). F. biol. Chem. 208, 845 .

Ely, J. O. \& Ross, M. H. (I95I). Science, N.Y. I14, 70.

Fiske, C. H. \& Subbarow, Y. (I929). F. biol. Chem. 8r, 629.

Folch, J., Lees, M. \& Stanley, G. H. S. (1957). F. biol. Chem. 226, 497.

Harper, A. E. (1959). \%. Nutr. 68, 405.

Kazantseva, V.S. \& Kaplanskii, S. Ya. (1956). Biokhimiya 2r, 528.

Kosterlitz, H. W. (1947). F. Physiol, Lond. ro6, 194.

Kshirsagar, S. G. \& Patwardhan, V. N. (1958). Indian F. med. Res. 46, 817.

Kumta, U. S. \& Harper, A. E. (1962). Proc. Soc. exp. Biol. Med. r10, 512.

Kumta, U. S., Harper, A. E. \& Elvehjem, C. A. (1958). J. biol. Chem. 233, I 505.

Lepkovsky, S. (1953). Adv. Fd Res. 4, 105.

Muramatsu, K. \& Ashida, K. (1962). F. Nutr. 76, 143.

Mayer, K. (1955). Ann. N.Y. Acad. Sci. 63, I5. 
Montgomery, R. (1957). Archs Biochem. Biophys. $67,378$.

Narasinga Rao, B. S. \& Radhakrishnan, M. R., (1966). Indian F. med. Res. 54, 40.

Platt, B. S., Heard, C. R. C. \& Stewart, R. J. C. (I964). In Mammalian Protein Metabolism. Vol. 2, p. 445. [H. N. Munro and J. B. Allison, editors.] New York: Academic Press Inc.

Prigmore, J. R., Bothwell, J. W. \& Williams, J. N. Jr (1955). Proc. Soc. exp. Biol. Med. 88, 43.

Rosen, F., Roberts, N. R. \& Nichol, C. A. (I959). F. biol. Chem. 234, 476.

Samuels, L. T., Goldthorpe, H. C. \& Dougherty, T. F. (r95 I). Fedn Proc. Fedn Am. Socs exp. Biol. 10, 393 .

Srinivasan, P. R. \& Patwardhan, V. N. (1955). Indian $\mathcal{F}$ med. Res. 43, I.

Sekhara Varma, T. N. \& Hanumantha Rao, R. (1966). Indian F. Biochem. 3, 37.

Schneider, W. C. (1946). F. biol. Chem. 164, 747.

Sidransky, H. \& Farber, E. (1958). Archs Path. 66, 1 I9.

Sidransky, H. \& Rechcigl, M. Jr (1962). F. Nutr. 78, 269.

Spector, H. \& Adamstone, F. B. (1950). F. Nutr. 40, 213.

Srikantia, S. G. (1963). A Rev. biochem. all. Res. India. 34, 9.

Srikantia, S. G., Venkatachalam, P. S., Reddy, V. \& Gopalan, C. (1964). Indian F. med. Res. 52, 1 I04.

Thompson, S. Y., Ganguly, J. \& Kon, S. K. (I949). Br. F. Nutr. 3, 50.

Thompson, R. Y., Heagy, F. C., Hutchison, W. C. \& Davidson, J. N. (I 953). Biochem. F. 53, 460.

Umbreit, W. W., Burris, R. H. \& Stauffer, J. F. (1957). In Manometric Techniques, 3rd ed., p. I73. Minneapolis: Burgess Publishing Company.

Van Pilsum, J. F., Speyer, J. F. \& Samuels, L. T. (1957). Archs Biochem. 68, 42.

Wainio, W. W., Eichel, B., Eichel, H. J., Person, P., Estes, F. L. \& Allison, J. B. (1953). J. Nutr. 49, 465 .

Waterlow, J. (1959). Nature, Lond. 184, 1875.

Williams, J. N. Jr (1961 a). F. Nutr. 73, I 99.

Williams, J. N. Jr (г 96, b). F. Nutr. 73, 2 го.

Young, E. G. \& Conway, C. F. (1942). Ұ. biol. Chem. 142, 839. 